\title{
LAPAROSCOPIC CHOLECYSTECTOMY REQUIRES CONVERSION IN FEW PATIENTS ONLY: A PROSPECTIVE STUDY OF 370 PATIENTS
}

\author{
Mahesh Gupta1 , Harpeet Kaur², Pawan Saini ${ }^{3}$ \\ ${ }^{1}$ Associate Professor, Department of Surgery, Rama Medical College Hospital and Research Centre, Mandhana, Kanpur, Uttar Pradesh. \\ ${ }^{2}$ Assistant Professor Department of Obstetrics \& Gynaecology, Rama Medical College Hospital and Research Centre, Mandhana, \\ Kanpur, Uttar Pradesh. \\ ${ }^{3}$ Senior Resident, Department of Surgery, MMIMSR, Mullana, Ambala.
}

\section{ABSTRACT}

\section{BACKGROUND}

Gallstone disease is a major health problem worldwide and laparoscopic cholecystectomy(LC) has become the gold standard surgical treatment of this entity. There are various complications related to this procedure which may lead to conversion into open cholecystectomy. We have done a prospective study of 370 cases in our institution to assess the reasons for conversion from LC to open cholecystectomy.

\section{MATERIAL AND METHODS}

370 cases of symptomatic gallstones were admitted in surgical unit of Rama Medical College Hospital \& Research Centre, Kanpur, U.P and all of them had undergone LC. The study was done prospectively from September 2013 to August 2015. All the patients with symptomatic gallstone disease including acute cholecystitis were included in this study and the reasons for conversion were recorded.

\section{RESULTS}

In our study we had to convert only $9(2.43 \%)$ cases out of 370 into open cholecystectomy and the most common reason found was dense adhesions and acutely inflamed gallbladder with a very low incidence of bile duct injury.

\section{CONCLUSIONS}

Despite of good selection of cases and experience of the operating surgeon few cases of laparoscopic cholecystectomy may require conversion into the open procedure.

\section{KEYWORDS}

Laparoscopic Cholecystectomy, Open Cholecystectomy, Acute Cholecystitis.

HOW TO CITE THIS ARTICLE: Mahesh Gupta, Harpreet Kaur, Pawan Saini. "Laparoscopic Cholecystectomy Requires Conversion in few Patients only: A Prospective Study of 370 Patients." Journal of Evolution of Medical and Dental Sciences 2015;

Vol. 4, Issue 98, December 07; Page: 16326-16328, DOI: 10.14260/jemds/2015/2410

\section{INTRODUCTION}

Gallstone disease is a major health problem worldwide and Laparoscopic Cholecystectomy (LC) has become the gold standard surgical treatment of this entity due to its advantages like shorter hospital stay, less postoperative pain, faster recovery and better cosmesis.1,2 There are various complications related to laparoscopy which include anaesthetic complications, complications of pneumoperitoneum like vascular injuries, visceral injuries, cardiac complications, pulmonary complications, air embolism and complications due to thermocoagulation, whereas specific complications of LC include hemorrhage, gallbladder perforation, bile leakage, bile duct injury and perihepatic collection. Along with these complications some patients may also suffer from biliary fistula, wound sepsis and hematoma. ${ }^{3-5}$ It is important to bear in mind that with the increased surgical experience and technical innovations, the indications for the laparoscopic approach to these complicated cases has increased to a larger extent, which obviates the need for conversion to open cholecystectomy. ${ }^{6-7}$

Financial or Other, Competing Interest: None.

Submission 17-11-2015, Peer Review 18-11-2015,

Acceptance 30-11-2015, Published 05-12-2015.

Corresponding Author:

Dr. Mahesh Gupta,

Associate Professor

Rama Medical College Hospital \& Research Centre, Mandhana,

Kanpur-209217, Uttar Pradesh.

E-mail: gm982003@yahoo.co.in

DOI:10.14260/jemds/2015/2410
However, conversion rates of $2.6 \%$ to $14 \%$ has been described in literature. We have done a prospective study of 370 patients in our institution to assess the reasons for conversion from LC to open cholecystectomy.

\section{MATERIALS AND METHODS}

Three hundred and seventy patients of symptomatic gallstones were admitted in surgical unit of Rama Medical College Hospital and Research Centre, Kanpur, UP, and all of them had undergone LC. The study was done prospectively from September 2013 to August 2015.

All the patients with symptomatic gallstone disease including acute cholecystitis, ultrasound proven cholelithiasis with normal CBD, patients with previous lower abdominal surgery were included in the present study. In patients with choledocholithiasis, LC was performed after clearance of CBD by Endoscopic Retrograde Cholangiopancreatography (ERCP). However, patients with previous upper abdominal surgery grossly derranged liver function tests, gallbladder malignancy, portal hypertension and severe cardiopulmonary disease or any other anesthaetic risks were not considered for this procedure.

In all these patients a routine history, physical examination, laboratory testing and ultrasound abdomen was done followed by written consent regarding the nature of the procedure and the possibility of conversion from the laparoscopic approach to open cholecystectomy. LC was performed in all these patients using standard four port technique by the same surgeon with an experience of more than 200 LCs. The reasons for conversion were recorded. 


\section{RESULTS}

Out of 370 patients of symptomatic gallbladder stone disease who had undergone laparoscopic cholecystectomy w.e.f. September 2013 till August 2015, 337(91.08\%) patients were female and only $33(8.91 \%)$ patients were male. All these patients were in the age group of 10-80 years (Table 1). Ultrasound abdomen suggested the presence of gallstones in all these cases; $347(93.78 \%)$ patients were operated on elective basis whereas $23(6.2 \%)$ patients presented as acute cholecystitis and were operated within IST 72 hours. In our study, we had to convert only $9(2.43 \%)$ patients out of 370 into open cholecystectomy and the most common reason found was dense adhesions and acutely inflamed gallbladder with a very low incidence of bile duct injury (Table-2.)

\section{DISCUSSIONS}

LC has become the gold standard treatment in symptomatic gallstone disease and it is the most common laparoscopic procedure, which is performed worldwide. ${ }^{8,9}$ However, some cases of LC needs to be converted into open procedure and this should not be considered as a complication, rather the safety of patient should always be considered. The conversion rate of $2.6 \%$ to $7.5 \%$ is reported in the literature along with the different reasons of conversion. ${ }^{10-13}$ in our study, conversion rate was $2.43 \%$, which favors the rates reported in the literature. The two most common reasons of conversion are dense adhesions at Calot's triangle and acute cholecystitis as suggested in the literature.6,9,14,15

This is also in correspondence to our present study. It is important to note while selecting the patients for LC that chronic inflammation and repeated attacks of acute cholecystitis lead to dense adhesion formation and thus dissection at Calot's triangle may sometimes become very difficult and necessitates the conversion into open procedure.

The reported conversion rates in acute cholecystitis range from $12 \%$ to $37.5 \% .^{16-19}$ In our study, only 23 cases had suffered from acute attack and out of this only 03(13.04\%) were converted. This rate of conversion in our study may be attributed to the low incidence of acute cases and all these acute cases were operated within IST 72 hours of presentation as within this period there is edema in the tissue planes, which magnify the structures and help in dissection.

In hepatobiliary surgeries, bile duct injury is one of the most serious complications and in LC especially there are reports of bile duct injury attributable to the inexperience and misinterpretation of anatomy by the operating surgeon. However, even in the expert hands this complication may occur at times during tough tissue dissection. The reported incidence of bile duct injuries in LC range from $0.59 \%$ to $2.9 \% .^{20-23}$ In our study, there was only one $(0.27 \%)$ case of bile duct injury which was detected intraoperatively and was repaired over t-tube after conversion. Such low incidence of this injury in our study is probably due to our selection of cases, experience and technique of LC. In our study, we have not encountered any other reason of conversion which are reported in the literature like injury to the bowel $(0.9 \%)$, bleeding through gallbladder bed or cystic artery injury (9.8\%). 1,24,25 This is probably due to overall policy in selection of cases and increasing experience.

\section{CONCLUSION}

Although laparoscopic cholecystectomy is the gold standard treatment for symptomatic gallstone disease, but few patients may require conversion especially if the selection of cases and the experience of surgeon is good and also it should be dependent upon the clinical judgment of the operating surgeon in regards to the safety of the procedure and patient.

\begin{tabular}{|c|c|c|}
\hline $\begin{array}{c}\text { Age Range } \\
\text { (Years) }\end{array}$ & $\begin{array}{c}\text { Laparoscopic } \\
\text { Cholecystomies } \\
\text { No. of Patients (370) }\end{array}$ & (\%) \\
\hline $10-19$ & 02 & 0.54 \\
\hline $20-29$ & 09 & 2.43 \\
\hline $30-39$ & 127 & 34.32 \\
\hline $40-49$ & 111 & 30.0 \\
\hline $50-59$ & 92 & 24.86 \\
\hline $60-69$ & 21 & 7.29 \\
\hline $70-79$ & 08 & 2.16 \\
\hline \multicolumn{2}{|c|}{ Table 1: Age Distribution } \\
\hline
\end{tabular}

\begin{tabular}{|c|c|c|}
\hline $\begin{array}{l}\text { Indications for } \\
\text { Conversion }\end{array}$ & $\begin{array}{c}\text { Number } \\
\text { of } \\
\text { Patients }\end{array}$ & $(\%)(n=370)$ \\
\hline $\begin{array}{l}\text { Dense adhesions at } \\
\text { Calot's triangle }\end{array}$ & 05 & 1.35 \\
\hline $\begin{array}{c}\text { Common bile } \\
\text { duct injury }\end{array}$ & 01 & 0.27 \\
\hline Total Patients & 09 & 2.43 \\
\hline \multicolumn{3}{|c|}{$\begin{array}{c}\text { Table 2: Indications for Conversion } \\
\text { to Open Cholecystectomy }\end{array}$} \\
\hline
\end{tabular}

\section{REFERENCES}

1. Shea JA, Healey MJ, Berlin JA, et al. Mortality and complications associated with laparoscopic cholecystectomy. A meta-analysis. Ann Surg 1996;224:609-620.

2. Reynolds W, Jr. The first laparoscopic cholecystectomy. JSLS: Journal of the Society of Laparoendoscopic Surgeons/Society of Laparoendoscopic Surgeons 2001;5:89-94.

3. Shamiyeh A, Wayand W. Laparoscopic cholecystectomy: early and late complications and their treatment. Langenbecks Arch Surg 2004;389:164-171.

4. Deziel DJ, Millikan KW, Economou SG, Doolas A, Ko ST, Airan MC. Complications of laparoscopic cholecystectomy: a national survey of 4,292 hospitals and an analysis of 77,604 cases. Am J Surg 1993;165:9-14.

5. Lee VS, Chari RS, Cucchiaro G, Meyers WC. Complications of laparoscopic cholecystectomy. Am J Surg 1993;165:527-532.

6. Lo CM, Fan ST, Liu CL, Lai EC, Wong J. Early decision for conversion of laparoscopic to open cholecystectomy for treatment of acute cholecystitis. Am J Surg 1997;173:513-517.

7. Sikora SS, Kumar A, Saxena R, Kapoor VK, Kaushik SP. Laparoscopic cholecystectomy - can conversion be predicted? World J Surg 1995;19:858-860.

8. Bittner R. Laparoscopic surgery-15 years after clinical introduction. World J Surg 2006;30:1190-1203.

9. Ros A, Gustafsson L, Krook H, et al. Laparoscopic cholecystectomy versus mini-laparotomy cholecystectomy: a prospective, randomized, single-blind study. Ann Surg 2001;234:741-749.

10. Bingener-Casey J, Richards ML, Strodel WE, Schwesinger WH, Sirinek KR. Reasons for conversion from laparoscopic to open cholecystectomy: a 10-year review. J Gastrointest Surg 2002;6:800-805.

11. Daradkeh S. Laparoscopic cholecystectomy: analytical study of 1208 cases. Hepatogastroenterology 2005;52:1011-1014.

12. Kama NA, Kologlu M, Doganay M, Reis E, Atli M, Dolapci M. A risk score for conversion from laparoscopic to open cholecystectomy. Am J Surg 2001;181:520-525. 
13. Rosen M, Brody F, Ponsky J. Predictive factors for conversion of laparoscopic cholecystectomy. Am J Surg 2002;184:254-258.

14. Kologlu M, Tutuncu T, Yuksek YN, Gozalan U, Daglar G, Kama NA. Using a risk score for conversion from laparoscopic to open cholecystectomy in resident training. Surgery 2004;135:282-287.

15. Peters JH, Krailadsiri W, Incarbone R, et al. Reasons for conversion from laparoscopic to open cholecystectomy in an urban teaching hospital. Am J Surg 1994;168:555-558; discussion 558-559.

16. Livingston EH, Rege RV. A nationwide study of conversion from laparoscopic to open cholecystectomy. Am J Surg 2004;188:205-211.

17. Lim KR, Ibrahim S, Tan NC, Lim SH, Tay KH. Risk factors for conversion to open surgery in patients with acute cholecystitis undergoing interval laparoscopic cholecystectomy. Ann Acad Med Singap 2007;36:631-635.

18. Biswas S, Saha J, Rahman M, Rahman M. Laparoscopic Cholecystectomy In Acute Calculus CholecystitisExperience At District Level Hospital. Faridpur Medical College Journal 2011;5.

19. Verma GR, Bose SM, Wig JD. Pericholecystic adhesions in single $\mathrm{v}$ multiple gallstones and their consequences for laparoscopic cholecystectomy. J Laparoendosc Adv Surg Tech A 2001;11:275-279.
20. Kwon AH, Inui H, Kamiyama Y. Laparoscopic management of bile duct and bowel injury during laparoscopic cholecystectomy. World J Surg 2001;25:856-861.

21. Huang Z-Q, Huang X-Q. Changing patterns of traumatic bile duct injuries: a review of forty years' experience. World J Gastroenterol 2002;8:5-12.

22. Misawa T, Koike M, Suzuki K, et al. Ultrasonographic assessment of the risk of injury to branches of the middle hepatic vein during laparoscopic cholecystectomy. Am J Surg 1999;178:418-421.

23. Mases A, Montes A, Ramos R, Trillo L, Puig MM. Injury to the abdominal aorta during laparoscopic surgery: an unusual presentation. Anesth Analg 2000;91:561-562.

24. Sicklick JK, Camp MS, Lillemoe KD, et al. Surgical Management of Bile Duct Injuries Sustained During Laparoscopic Cholecystectomy. Ann Surg 2005;241:786-795.

25. Gharaibeh KI, Ammari F, Al-Heiss H, et al. Laparoscopic cholecystectomy for gallstones: a comparison of outcome between acute and chronic cholecystitis. Ann Saudi Med 2001;21:312-316. 